\title{
Implementation of a Forest Biomass-based Biofuel Industry: A Canadian Experience
}

\author{
Mariya Marinova, Michel Perrier and Jean Paris \\ Department of Chemical Engineering \\ Research Unit on Energy Efficiency of the Forest Biorefinery $\left(E^{2} D^{2} B F\right)$ \\ École Polytechnique \\ P.O. Box 6079 Station Centre-ville, Montréal, QC, Canada H3C 3A7 \\ Phone: +1-514-340-4711 ext. 4921, e-mail: Jean.Paris@polymtl.ca
}

\begin{abstract}
The forest biomass is an abundant renewable resource from which biofuels can be derived. In the Kraft process the cellulose is extracted from the wood to form the paper pulp while the other organic components, primarily hemicelluloses and lignin, are burnt to produce steam. It is possible to divert part of the hemicelluloses or lignin to produce fuels on site, a mode of operation referred to as the integrated forest biorefinery. Hemicelluloses can be hydrolysed into sugars which in turn are converted into ethanol or butanol while lignin can be extracted from a residual process stream, the black liquor, by acid precipitation, de-ionized, dried and directly used as a fuel or further processed into value added chemicals. Biorefinery processes have been proposed and analysed by simulation on ASPEN PLUS.

Intensive integration of thermal energy, water and material systems is of paramount importance to the sustainability of the global site; the increased energy load on the utility systems could cause rising dependency of the global site on fossil fuels. To avoid this consequence, a new original energy efficiency analysis an enhancement methodology has been developed and validated on actual Canadian Kraft mills before being applied to the integrated biorefinery and has produced remarkable results far superior to the current engineering practice. This has led to the concept of the green integrated forest biorefinery (GIFBR). i.e. an industrial site with zero fossil fuel consumption and reduced GHG emissions vs. the Kraft process and biorefinery plant alone. The GIFBR incorporates a woody biomass gasifier producing syngas as a fuel for the integrated biorefinery and for steam production or sale. It can also include a combined heat and power (CHP) unit driven by steam made available by liberated production capacity from the installed power plant.
\end{abstract}

\section{Key words}

Wood biomass conversion, Renewable energy, Integrated forest biorefinery, Biofuels, Kraft lignin extraction, Bioethanol, Green forest biorefinery, Energy efficiency enhancement.

\section{Introduction}

The concentration of $\mathrm{CO}_{2}$ in the atmosphere has increased constantly since the onset of the industrial revolution. The concentration in the mid-eighteen century has been estimated at $280 \mathrm{ppm}$; it reached $400 \mathrm{ppm}$ in 2013, an alarming level. The goal of the Kyoto Protocol (1997), stabilization at about $550 \mathrm{ppm}$ in 2050 , will probably be exceeded, as illustrated on Figure 1. The return to an anterior level is probably impossible; the current rate of growth of the accumulation of $\mathrm{CO}_{2}$ in the higher atmosphere could have catastrophic effects on the climate of our planet. The implementation of measures in three domains individually or in combinations have been identified as potentially effective means to control $\mathrm{CO}_{2}$ emissions and stabilize its concentration in the atmosphere [2]:

- Rational use of energy,

- Development of renewable sources of energy,

- Creation of carbon sinks.

The development of biofuels derived from the forest biomass could contribute significantly to the implementation of such measures [3].

\section{The potential role of the forest sector}

The forest biomass in an abundant, renewable resource with zero carbon footprint provided the forest feedstock is renewed at a rate at least equal to that at which it is consumed.

This paper presents an approach based on the three principles given above which is being currently developed and implemented on a small scale by the pulp $\&$ paper (P\&P) sector in countries with mature forest industry $[4,5,6]$. It consists of implementing wood fractionation and conversion plants into existing $\mathrm{P} \& \mathrm{P}$ facilities while maintaining their core manufacturing of cellulose-based products. This approach is the P\&P mill based integrated forest biorefinery (IFBR), schematically illustrated in Figure 2 [7]. It benefits from direct on-site availability of feedstock, from the possibility of sharing installed infrastructures and, from the availability of a competent manpower. 


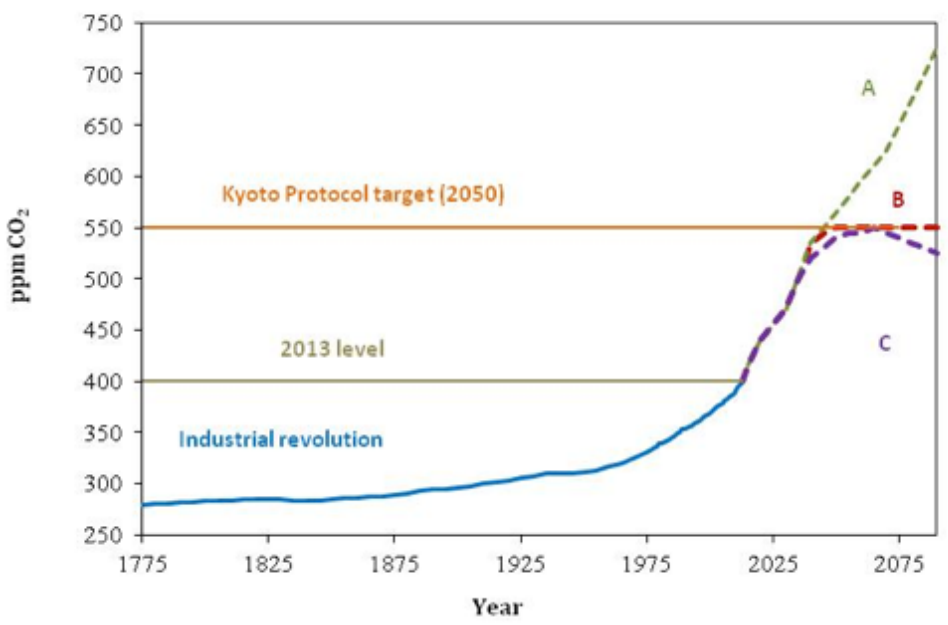

Figure 1. Impact of human activities on the concentration of $\mathrm{CO}_{2}$ in the atmosphere (after [1])

It is clearly advantageous from the technical and economic standpoint over stand-alone biorefiney plants and could generate additional revenues for the P\&P industry.

It also entails technical challenges such as the increasing thermal energy and water demand and the resulting risk of higher fossil fuel dependency and GHG emissions; also, the material integration between biorefinery and $P \& P$ process may cause detrimental components imbalance in key process streams requiring remedial action.

The receptor P\&P facility chosen for this work is the Kraft pulping mill, the prevalent pulping process worldwide. A schematic of the Kraft process is shown in Figure 3. A brief description of the principles of the Kraft process is given later.

Wood is composed of three main organic components cellulose, hemicelluloses and lignin. Typical compositions of hard and soft wood available in Canada are given in Table I. Cellulose, the main component of paper is retained by the
Kraft receptor mill process line to manufacture a pulp used to produce a paper type product. Part of the hemicelluloses or lignin is withdrawn from a process stream and used as feedstock to the adjunct biorefinery plant.

Table I. - Typical organic contents of wood (\%)

$\begin{array}{lcccc} & \underline{\text { Cel. }} & \text { Hemi. } & \text { Lign. } & \text { Minors } \\ \text { Coniferous } & 42 & 27 & 28 & 3 \\ \text { Residuous } & 42 & 30 & 20 & 3\end{array}$

Kraft pulping is a chemical delignification process of wood chips under strongly basic, high temperature and pressurized conditions, carried out in batch or continuous reactors [8]. Most of the organic and inorganic components of the wood are solubilized except the cellulose which largely resists the treatment.

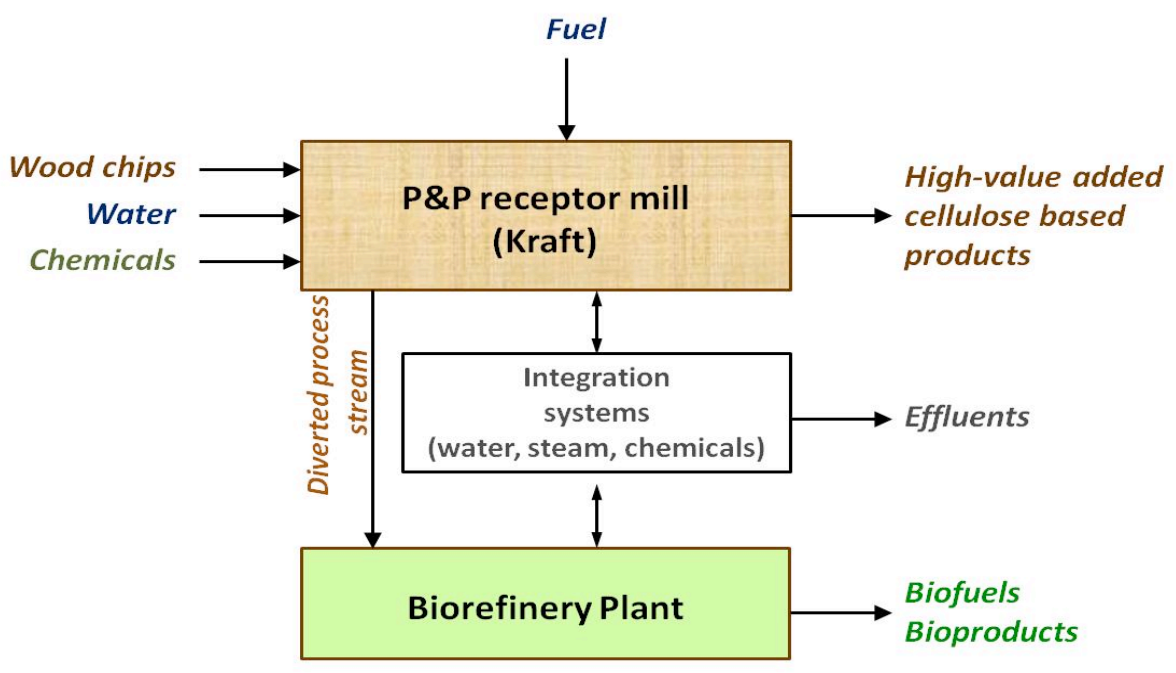

Figure 2. Concept of integrated forest biorefinery 




Figure 3. Schematic of Kraft process with points of withdrawal of hemicelluloses or lignin

The subsequent operations consist of separating and purifying the cellulose fibers as a dilute suspension in water, the pulp, which is finally dried and shipped for further processing. The spent delignification liquor (black liquor) is burnt in the recovery boiler to produce steam. The reactants dissolved in the black liquor form a smelt which is recaustified and returned to the digester.

Figure 3 indicates the points at which a hemicelluloses or lignin stream can be withdrawn from the core Kraft process. Two main types of pulp are currently manufactured by Canadian Kraft mills: standard paper pulp and viscose pulp. Viscose pulp, also called dissolving pulp, is a high purity material used as precursor to downstream chemicals.

\section{The hemicelluloses biorefinery}

Hemicelluloses constitute a class of wood components that can be converted into valuable derivatives rather than being burnt off as it is in typical Kraft pulp mills. They can be extracted from wood chips and converted into sugars by hydrolysis. Those sugars can in turn be transformed into biofuels such as ethanol or butanol by fermentation [9].
An integrated ethanol process has been designed (Figure 4). Work on a butanol plant is in progress. An important objective of the design is that the biorefinery must have a low impact on the material and energy balance of the receptor mill. The processes have been simulated using the commercial software Aspen Plus ${ }^{\circledR}$. The integration of the ethanol process into an eastern Canadian dissolving pulp mills has been performed. A new technology has been implemented in this process to enhance its performance, the utilization of membranes to concentrate and purify the hydrolysates (removal of impurities and fermentation inhibitors).

\section{The lignin biorefinery}

Lignin, which is currently burnt in the Kraft recovery boiler, can be extracted by acid precipitation (Figure 5) and converted into biomass-based fuel [10]. Extraction of lignin can also be used to debottleneck an overloaded recovery boiler thus allowing mills to increase the pulp production. The withdrawal of lignin from the black liquor of a Kraft pulping process causes an imbalance in the ionic make-up at key operation levels; remedial measures have been proposed. The acid precipitation is at the pilot plant stage.

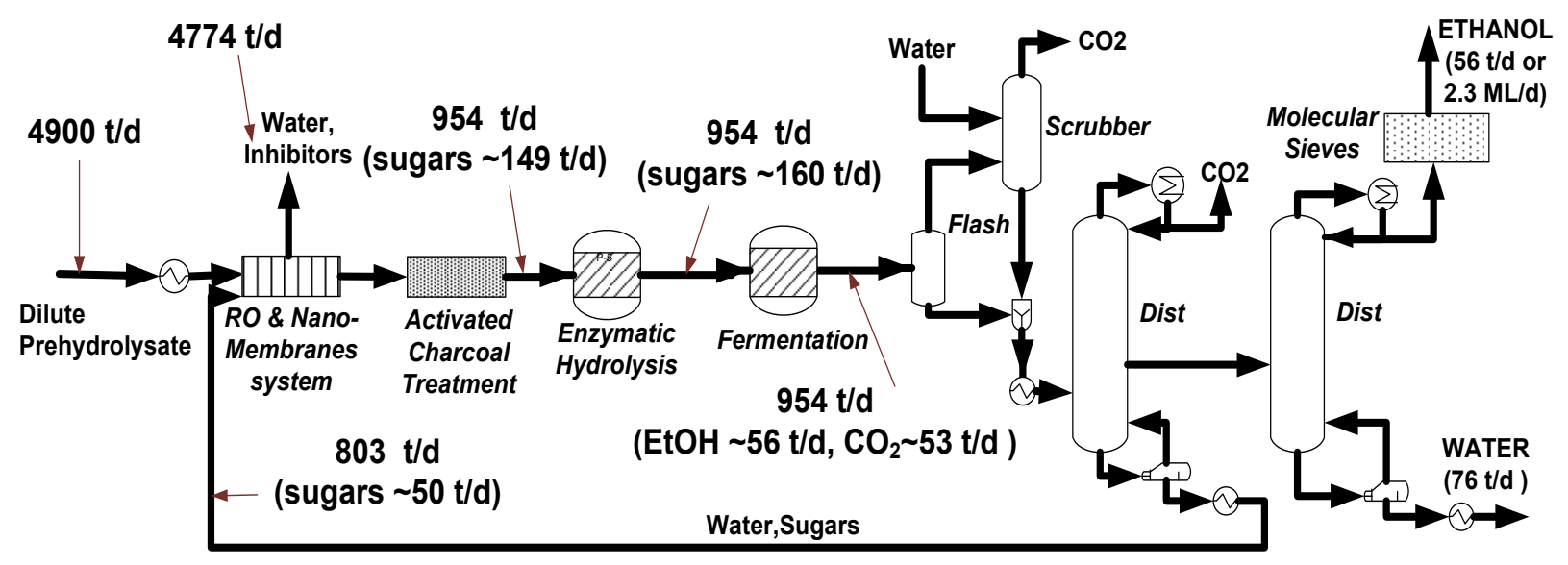




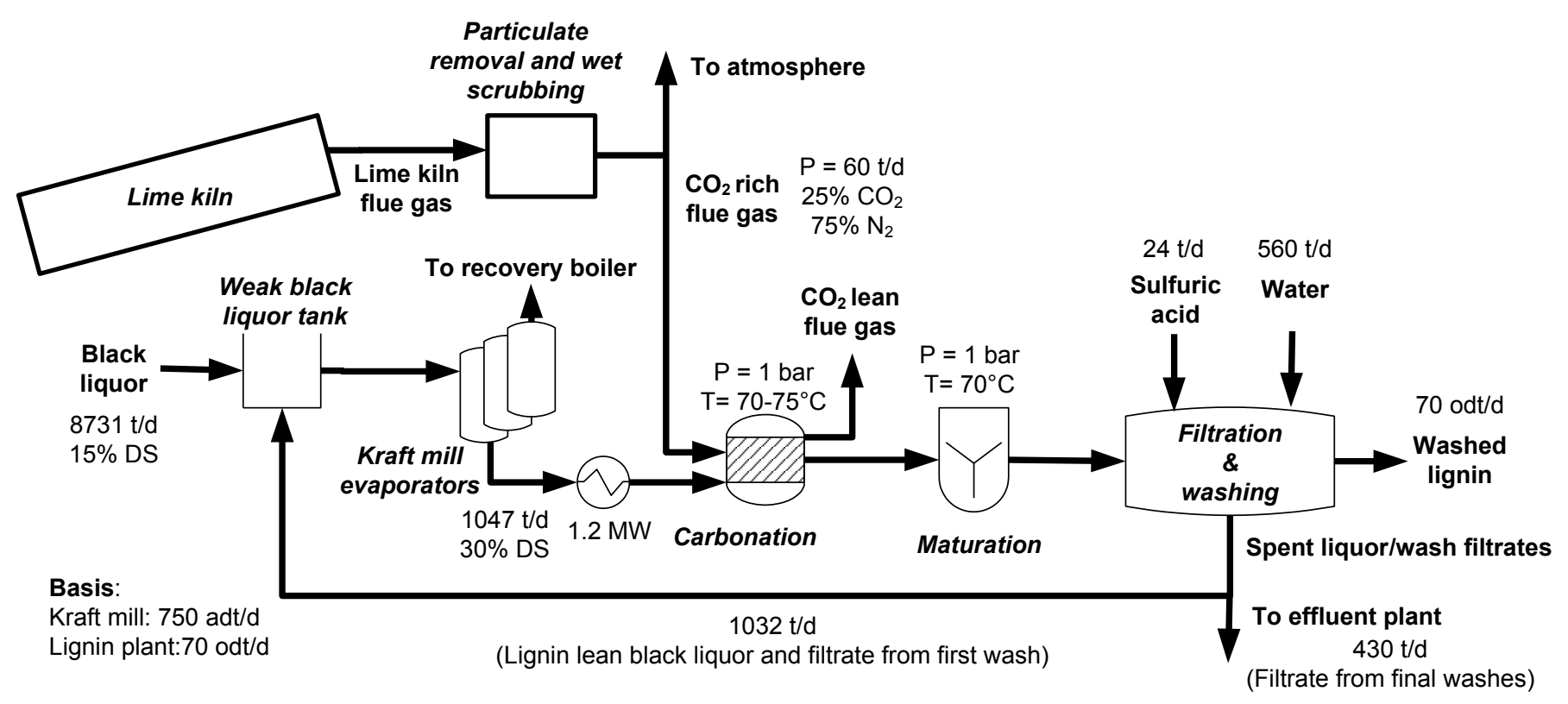

Figure 5. Black liquor to lignin biorefinery

However some issues are still unresolved and work has been done on the capture and utilisation of $\mathrm{CO} 2$ from stack gases from the lime kiln that produces the make-up lime used in the recausticizing loop (Figure 4) and its utilization for the precipitation stage. Laboratory scale experimental work has also been undertaken on the formation of lignin flocks and, on their filterability.

\section{The green integrated forest biorefinery}

The green integrated forest biorefinery (GIFBR) is a multirevenue generating industrial complex composed of four units: a Kraft receptor mill, a biorefinery plant producing bio-fuel (ethanol, butanol or lignin), a woody biomass gasification plant and a polygeneration unit to produce green power (Figure 6). The GIFBR is characterized by low emissions of GHG, low discharge of water borne effluents and more importantly, by a zero fossil fuel consumption.

The technical and economic feasibility of the GIFBR has been established. Integration studies for a GIFBR composed of a dissolving pulp mill and a biorefinery for ethanol production has been carried out.
It has been shown that, with appropriate mass and energy integration, the Kraft mill receptor could support the implementation of the biorefinery plant while reducing its $\mathrm{CO}_{2}$ emissions. The possibility of incorporating a woody biomass gasification to produce syngas for the lime kiln has also been carried out. The results demonstrate that the syngas produced could substitute the fossil fuel thus meeting the complete requirement of a green facility. The implementation of the gasification unit is then clearly advantageous from both an environmental and an economic point of view. However due to high investment costs, the implementation of a gasification unit only to support a fossil fuel free facility may not be viable. Various pathways to potential products from syngas (including heat and electricity production or biofuels such as FT diesel) have been evaluated [11]. To support To support this work a new model of the biomass gasification process has been developed. It uses a conventional pseudo-equilibrium thermodynamic approach with concentration ratios derived from experimental data.

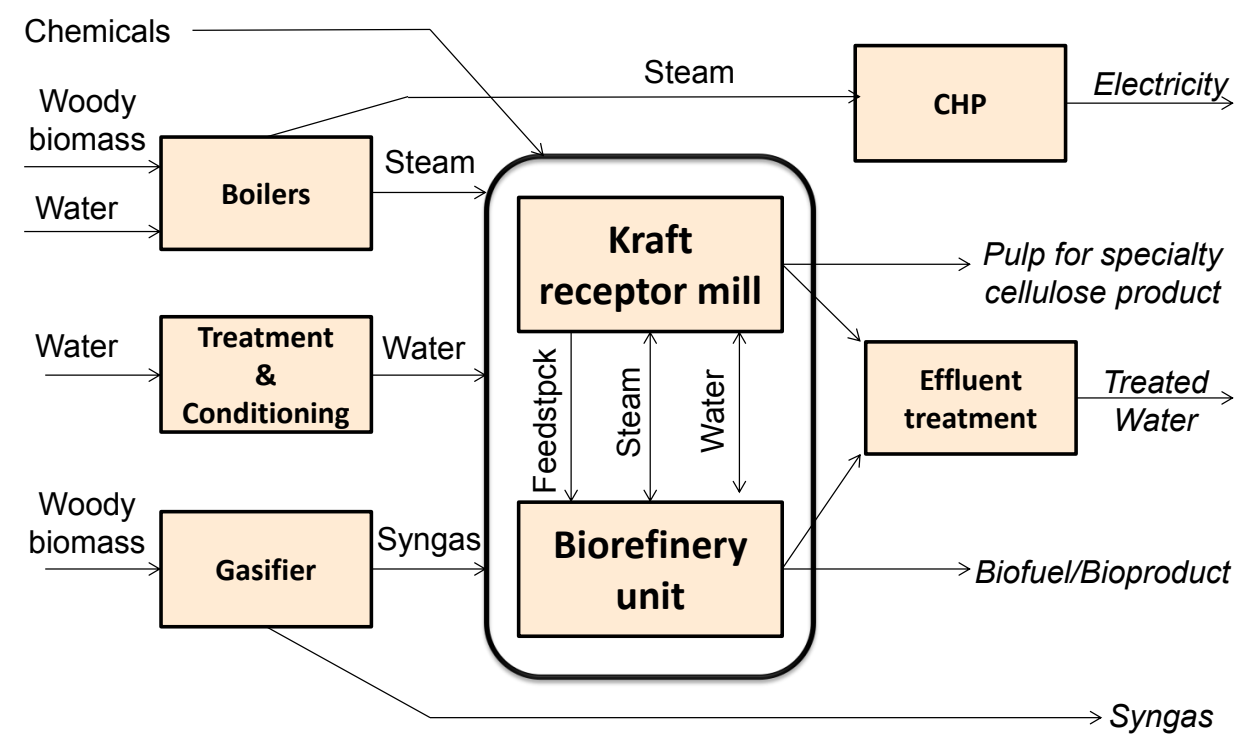






Figure 7. Methodology diagram

\section{Energy efficiency analysis and enhancement}

The sustainability of the integrated forest biorefinery will largely depend on the energy efficiency of the global site. A novel process integration and energy efficiency enhancement methodology based on a project approach has been developed and applied to operating Canadian Kraft mills [12]. A particularity of this methodology is that it treats simultaneously the steam and water utility systems. Figure 7 presents a schematic diagram of the methodology consisting three steps.

- The development of a data base, a detailed process simulation focused an energy networks and, the characterization of the current energy performance level of the mill.

- Steam and water saving projects are identified [12]. It is frequent that, in a plant such as a pulping mill which has been operating for an extended period, some unit operations deviate appreciably from their intended operating conditions.

- Utilizing the results of the previous step a diagnostic is made and remedial actions are taken. In the following step a large number of efficiency enhancement projects are identified and documented by simulation and finally, a new, optimized heat exchanger network is developed. The techniques used in those two steps are novel and original.

- A post analysis in which the progress achievable over current performance is quantified and a stepwise implementation strategy that takes into account the company business plan is formulated.

The application of the method to three Kraft mills has produced remarkable results far superior to the current engineering practice. These mills are geographically distributed across Canada and represent a spectrum of operating conditions typical of the industry.
The application of the method to three Kraft mills has produced remarkable results far superior to the current engineering practice. These mills are geographically distributed across Canada and represent a spectrum of operating conditions typical of the industry.

\section{Conclusion}

In order to stabilize the concentration of GHG, and in particular of $\mathrm{CO}_{2}$, in the atmosphere, a broad range of measures will have to be implemented. They may require profound changes of behavior. People transportation as we know it today will definitely not be sustainable; it is too efficient from the stand point of energy usage. Energy efficiency in all human activities and on a very large scale is central to the control of global warming.

The work presented above focuses on a very specific but potentially significant contribution to the control of global warning: the use of forest biomass as a feedstock for the production of fuels with a zero net carbon footprint since, in the course of its lifetime, a tree will absorb approximately the same amount of $\mathrm{CO} 2$ as would be released in the conversion of its mass into thermal energy.

Actually, if the stock of forest is increased the excess $\mathrm{CO} 2$ of the forest biomass growth over its consumption will act as a carbon sink. Furthermore, the forest has an advantage over energy crops inthat it does not compete with food crops for available land.

The forestry sector in many countries has become aware of this unique position and building on an extremely vast and solid base of knowledge and experience and on extensive infrastructure has embarked on a new adventure, the sustainable production of wood biomassbased fuels and other value added products. 
The work presented in this paper presents a much focused initiative, the implementation of the forest biorefinery in Kraft pulping mills which could be a critical step in the evolution of the forestry sector as a major manufacturer of renewable and sustainable bio-fuels. More specifically, this work deals with the implementation of the green integrated biorefinery.

The green integrated forest biorefinery is a concept that appears capable of producing a variety of green biofuels while generating additional revenues for the P\&P industry provided the global site is highly integrated and optimized from the standout of thermal energy. This type of approach, if generalized to other P\&P processes, could significantly contribute to the stabilization of the $\mathrm{CO} 2$ concentration in the atmosphere. A fundamental aspect of this work, the development of a novel and superior methodology for the analysis and enhancement of energy efficiency could be generalized to other material converting industries such as mining, chemical and food processing.

\section{Acknowledgments}

This work was supported by an R \& D Cooperative grant of the National Science and Engineering Research Council of Canada and by the BioFuelNet network. The authors are also indebted to the students who have contributed to this work: R. Ammara, O. Ajao, S. Ben Cheikh, M. Kannangara, M. Keshtkar, T. Rafione, F. Zasieczny.

\section{References}

1. National Oceanic \& Atmospheric Administration (2013), "Trends in Carbon Dioxide", at www.esrl.noaa.gov/gmd/ccgg/trends

2. Meunier, F. (2008), "Domestiquer l'effet de serre, Énergie et changement climatique" Dunod ed.

3. Towers M., Browne T., Kerekes R., Paris J. \& Tran H. (2007), "Biorefinery Opportunities for the Canadian Pulp \& Paper Industry", P\&P Can., 108 (6); 26-9.

4. Mateos-Espejel E., Alva-Argaez A., Savulescu L. \& Paris J. (2010), "From Kraft Mills to Forest Bioref., Energy \& Water Perspective", Cellulose Chemistry \& Technology, Part I : Methodology, 44 (1-3); 15-9.

5. Marinova M., E Mareos-Espejel E., Paris J. (2010), "From Kraft Mills to Forest Bioref., Energy \& Water Perspective", Cellulose Chemistry \& Technology, Part II : Case Study, 44 (1-3); 21-6.

6. Cherubini, F., Jungmeier, G., Wellisch, M. Willke, T., Skiadas, I., Van Ree, R. \& John, E. (2009), "Toward a common classific. approach for biorefinery systems", Biofuels, Bioprod. Biorefin, 3 (5), 534-546.
7. Perrier, M. Keshtkar, M. Rafione, T. Ajao, O \& Rafouie, P. (2013), "The Integrated Forest Biorefinery \& Protection of the Environment", $3^{\text {rd }}$ Intern'l Forest Biorefinery Symposium, $99^{\text {th }}$ Paperweek Can., Montreal.

8. Smook, G.A., Handbook for Pulp and Paper Technology (2012), $3^{\text {rd }}$ Ed., Angus Wilde Pub. Vancouver.

9. Palmqvist, E., \& Hahn-Hagerdal, B. (2000), "Fermentation of lignocellulosic Hydrolysates, I: inhibition and detoxification", Biores. Technol., $74 ; 17-24$.

10. Kouisni, L., Holt-Hindle, P., Maki, K. \& Paleologou, M. (2013), "The LignoForce system ${ }^{\mathrm{TM}}$ : A new process for the production of high-quality lignin from black liquor", J-FOR, 2: 6-10.

11. Rafione, T., Marinova, M., Montastruc, L., Domenech, S., Srinivasan, B., \& Paris, J. (2013), "Optimization of Water \& Energy Consumption in an Integrated Forest Biorefinery", J-FOR, 2 (4): 549.

12. Keshtkar, M. J., Moshkelani, M., Garza Villareal, H., Ammara, R., (2012), "Energy Supply for an Integrated Forest Biorefinery: Energy Performance Analysis of a Kraft Mill", Proc. 2 $2^{\text {nd }}$ Intern'l Forest Bioref. Symp., $98^{\text {th }}$ PaperWeek Canada, 1076-93, Montreal. 